JKEP

Vol 6, No 2 (2021)

ISSN: 2338-9095 (Print)

ISSN: 2338-9109 (online)

\title{
Gambaran Kualitas Hidup Pasien Pasca Mengalami Cedera Kepala: Literature Review
}

\author{
Nanda Agustia, Gamya Tri Utami, Fathra Annis Nauli \\ Program Studi Keperawatan Fakultas Keperawatan \\ Universitas Riau \\ Email: ananda.agst98@gmail.com
}

Artikel history

Dikirim, Sept 04th, 2020

Ditinjau, Nop 16th, 2021

Diterima, Nop 23th, 2021

\begin{abstract}
Head injury is a type of trauma that is commonly found in emergency departements, this is evidence by the large number of deaths resulting from the incidence of head injuries. if the patient survives and they will have physiological or anatomical disorders that affect to the quality of life. The purpose of this literature study is to find out the quality of life of patients after suffering a head injury. The method used is a literature study obtained from scientific reseach article that searches in accordance with the inclusion criteria, start from 2015 up to 2019 using Google Scholar,Science Direct, and Pubmed. The keyword used are Quality of life, Head Injury. Based on 7 research articles, it was found that 6 out 7 articles stated that there was a decrease in quality of life in post-injury patients with duration of 3, 6, and 12 months, evaluation quality of life the domain of assessment of quality of life that experienced the most decrease was in the physical, psychological, social and cognitive domains, 1 research article stated that there was increase in quality of life after head injury. Based on result there was a decrease in quality of life in post- injury patients.
\end{abstract}

Keywords: Head Injury, Quality of Life

\begin{abstract}
ABSTRAK
Cedera kepala merupakan jenis trauma yang banyak ditemukan di unit gawat darurat, hal ini dibuktikan dari banyaknya jumlah kematian yang diakibatkan dari kejadian cedera kepala. Pasien pasca cedera kepala yang bertahan hidup akan mengalami gangguan baik fisiologis atau anatomis yang berpengaruh terhadap kualitas hidup, dalam literature review ini peneliti ingin mengetahui bagaimana gambaran dari kualitas hidup pasien pasca mengalami cedera kepala. Tujuan dari studi literature ini adalah untuk mengetahui gambaran kualitas hidup pasien pasca mengalami cedera kepala. Metode yang digunakan adalah studi literature diperoleh dari penelusuran artikel penelitian ilmiah sesuai dengan kriteria inklusi yaitu dari rentang tahun 2015-2019 dengan menggunakan Google Scholar, Science Direct, Pubmed. Kata kunci yang digunakan adalah Quality of life, Head Injury. Berdasarkan 7 artikel penelitian didapatkan hasil bahwa 6 dari 7 artikel menyatakan terdapat penurunan kualitas hidup pada pasien pasca mengalami cedera kepala dengan durasi 3, 6, dan 12 bulan, Penilaian kualitas hidup paling banyak mengalami penurunan pada domain, fisik, psikologis, sosial, dan kognitif, 1 artikel penelitian
\end{abstract}


menyatakan terdapat peningkatan kualitas hidup pasca cedera kepala. Berdasarkan hasil dari artikel menyatakan terdapat penurunan kualitas hidup pada pasien pasca mengalami cedera kepala.

Kata Kunci: Cedera Kepala, Kualitas Hidup

\section{PENDAHULUAN}

Cedera kepala merupakan jenis trauma yang banyak ditemukan di unit gawat darurat, hal ini dibuktikan dengan banyaknya jumlah kematian yang diakibatkan dari kejadian cedera kepala (ATLS, 2018). Data terbaru dari Amerika Serikat memperkirakan sekitar 1.700 .000 mengalami cedera kepala setiap tahunnya, termasuk 275.000 pasien dengan rawat inap dan 52.000 pasien dengan kematian. Data lainnya didapatkan angka kejadian cedera kepala di Singapura sebesar $42,3 \%$ yang dirujuk ke ruangan departemen darurat bedah (ATLS, 2018).

Data Riskesdas tahun 2018 angka kejadian cedera kepala di Indonesia menepati angka $11,9 \%$, sementara angka kejadian cedera kepala di Provinsi Riau menepati angka 10\% dari ratarata nasional kejadian cedera kepala.

Cedera kepala yakni istilah luas yang menggambarkan sejumlah besar cedera yang berlangsung pada kulit kepala, tengkorak, otak, dan jaringan dibawahnya serta pembuluh darah di kepala baik berupa cedera terbuka maupun cedera tertutup (Haryono \& Utami, 2019). Cedera kepala adalah suatu gangguan traumatik yang melibatkan fungsi otak yang disertai atau tanpa perdarahan interstisial dalam substansi otak tanpa diikuti terputusnya kontinuitas otak
(Tarwoto, 2013). Cedera kepala dapat menimbulkan beberapa efek berdasarkan beratnya cedera kepala.

Pasien cedera kepala ringan biasanya akan menimbulkan efek seperti: sakit kepala, sensasi berputar, kebingungan ringan, mual, denging di telinga. Keadaan cedera kepala berat akan menimbulkan efek: kehilangan kesadaran, kejang, disorietasi serius, sakit kepala terusmenerus atau memburuk, hilangnya ingatan (Haryono \& Utami, 2019).

Ditinjau dari efek yang ditimbulkan pasca mengalami cedera kepala baik fisiologi maupun anatomis serta prognosis pada pasien pasca mengalami cedera kepala tentunya akan berpengaruh terhadap mutu hidup. Menurut World Health Organization Quality of Life (WHOQOL) kualitas hidup yakni sebagai persepsi pribadi terhadap kehidupannya di masyarakat dalam konteks budaya dan sistem nilai yang ada terkait dengan tujuan hidup, harapan, standar, dan perhatian (Dewi, 2014).

Pasien cedera kepala akan mengalami perubahan dalam kualitas hidup diantaranya, merubah daya konsentrasi, mempengaruhi kecepatan berfikir, mempengaruhi ingatan, berpengaruh dalam pengambilan keputusan, mengalami perubahan dalam diri menjadi lebih 
lambat, serta berdampak pada kekuatan diri yang menurun (Siponkoski, et al.2013).

Berdasarkan Penelitian lainnya yang dilakukan oleh Zwingly, P, et al. (2015) hasil penelitian didapatkan bahwa sebagian besar responden melaporkan puas terhadap mutu hidup mereka sehabis luka kepala pasca pembedahan, tetapi sebagian tidak merasa puas dengan hidupnya, berdasarkan pengakuan dari responden ketidak puasan responden terletak pada bidang- bidang kehidupan yang berarti, tercantum kesehatan serta gunanya dalam perihal psikologis, spritual, sosial, ekonomi serta sokongan keluarga.

Studi pendahuluan yang dilakukan di Kota Pekanbaru melalui wawancara dengan 3 pasien pasca mengalami cedera kepala berdasarkan jenis cedera kepala yang dialami terhadap kualitas hidup pasca mengalami cedera kepala. dari domain kognisi pada item konsentrasi 3 orang pasien mengatakan konsentrasinya sedikit terganggu seperti pada saat belajar dan saat melakukan pekerjaan dikantor, pada domain diri (self) dalam item energi atau kekuatan 2 dari 3 orang pasien mengatakan pasca mengalami cedera kepala berdampak pada kekuatan dirinya seperti tidak terlalu kuat untuk mengangkat barang berat dan berdiri terlalu lama, pada domain otonomi dan kegiatan sehari-hari pada item partisipasi dalam pekerjaan 3 orang pasien mengatakan masih bisa berpartisipasi dalam melakukan pekerjaan atau kegiatan lainnya.

Pada domain hubungan sosial dalam item hubungan dengan anggota keluarga 3 orang pasien mengatakan tidak mengganggu hubungan dengan anggota keluarga lainnya sama seperti sebelum mengalami cedera kepala, pada domain emosional dalam item depresi 3 orang pasien mengatakan tidak ada mengalami depresi atau kemurungan. Pada domain masalah fisik dalam item efek Traumatic Brain Injury (TBI) saat ditanyakan apakah masih sering merasakan sakit pada kepala, 2 dari 3 orang pasien mengatakan kadang-kadang masih merasakan pusing dan sakit pada bagian kepala saat terlalu lama beraktivitas.

Dari hasil studi pendahuluan yang telah dilakukan pada beberapa responden peneliti tertarik untuk melakukan penelitian terkait bagaimana kualitas hidup pada pasien pasca mengalami cedera kepala yang dilihat dari beberapa aspek domain penting yang mendasar dalam kehidupan.

\section{METODE PENELITIAN}

Topik yang diteliti dalam literature review ini adalah Gambaran kualitas hidup pasien pasca cedera kepala. Sehingga pada tahap screening peneliti melakukan pencarian data melalui website portal-artikel yang dapat diakses seperti (google scholar, Science direct, dan pubmed) dengan menggunakan kata kunci 
Quality of life AND Head injury OR Traumatic brain injury OR Brain injury.

Peneliti melakukan pencarian data dengan kriterian inklusi: 1) artikel dengan topik kualitas hidup pasca cedera kepala, 2) rentang waktu penerbitan jurnal yaitu 5 tahun (20152019), 3) artikel dapat diakses secara penuh (full text), 4) artikel dalam Bahasa Inggris, 5) original artikel. Kriteria inklusi sampel: 1) subjek yang diteliti manusia dewasa dari 17-70 tahun, 2) pasca mengalami cedera kepala 3, 6, 12 bulan.

Setelah proses screening dapat diketahui pasti dari jumlah awal data yang dimiliki berapa yang masih memenuhi syarat untuk selanjutnya dianalisa lebih jauh. Dalam literature review ini ektraksi data dipaparkan menggunakan tabel yang berisikan tentang nama penulis, tahun, judul artikel, tujuan penelitian, metode penelitian, sampel dan hasil penelitian, kekurangan, kelebihan dalam isi artikel.

Pada literature review ini peneliti menggunakan beberarapa website untuk mengakses artikel penelitian. Pencarian pada situs Google Scholar didapatkan sebanyak
60,100 artikel, pencarian pada situs Science Direct sebanyak 21,100 artikel dan pada situs Pubmed 2,498 artikel didapatkan total artikel sesuai kata kunci sebanyak 85, 698 artikel.

Selanjutnya sebanyak 85,618 artikel tereliminasi karna tahun terbit dibawah tahun 2015 sehingga didapatkan 80 artikel yang teridentifikasi terbitan tahun 2015- 2019 dan full text, selanjutnya dilakukan kembali eliminasi sebanyak 52 artikel karna tidak sesuai dengan tema gambaran kualitas hidupa pasca cedera kepala, sehingga tersisa sebanyak 28 artikel yang di screening berdasarkan judul. Selanjutnya peneliti melakukan screening kembali, didapatkan 21 artikel yang tereliminasi karna tidak sesuai dengan kriteria inklusi, sehingga didapatkan 7 artikel yang sesuai dengan kriteria inklusi yang sudah ditetapkan peneliti, yaitu artikel yang terkait dengan kualitas hidup pasien pasca cedera kepala, artikel dalam bahasa inggris, dapat di akses full text, tahun terbit 2015-2019, original artikel, subjek manusia dewasa 17- 70 tahun, pasca mengalami cedera kepala 3, 6 dan 12 bulan. 
HASIL LITERATURE REVIEW

\begin{tabular}{|c|c|c|c|c|}
\hline No & $\begin{array}{l}\text { Nama Penulis, } \\
\text { Tahun dan } \\
\text { Judul Artikel }\end{array}$ & $\begin{array}{c}\text { Tujuan } \\
\text { Penelitian }\end{array}$ & Metode Penelitian & Hasil Penelitian \\
\hline 1. & $\begin{array}{l}\text { (Dainter, } \\
\text { Mckinley, \& } \\
\text { Grace, 2019) } \\
\text { Change in life } \\
\text { roles and quality } \\
\text { of life for older } \\
\text { adults after } \\
\text { traumatic brain } \\
\text { injur }\end{array}$ & $\begin{array}{l}\text { Tujuan dalam } \\
\text { penelitian ini } \\
\text { untuk } \\
\text { membandingkan } \\
\text { perubahan peran } \\
\text { kehidupan dan } \\
\text { kualitas hidup, } \\
\text { kinerja aktivitas } \\
\text { sehari-hari, } \\
\text { antara orang } \\
\text { dewasa dengan } \\
\text { mTBI dan OI }\end{array}$ & $\begin{array}{l}\text { Desain Penelitian: } \\
\text { (Desain penelitian tidak } \\
\text { dijelaskan) } \\
\text { Sampel: jumlah sampel } \\
\text { keseluruhan } 30 \text { orang, } \\
\text { dengan pembagian } 15 \\
\text { pasca cedera kepala, } 15 \\
\text { orang dengan OI } \\
\text { Instrumen: Quesioner } \\
W H O Q O L-100\end{array}$ & $\begin{array}{l}\text { Penelitian ini didapatkan hasil yang } \\
\text { menyatakan bahwa orang dewasa yang } \\
\text { lebih tua dengan TBI mengalami lebih } \\
\text { banyak kehilangan peran, memiliki } \\
\text { kualitas hidup yang lebih rendah pada: } \\
\text { - Domain fisik dengan nilai rata-rata } \\
11.27 \\
\text { - Domain psikologis dengan nilai rata- } \\
\text { rata } 12.68 \\
\text { - Domain kebebasan } 12.60 \\
\text { - Domain hubungan sosial } 12.52 \\
\text { - Domain lingkungan } 14.47 \\
\text { - Domain spritual } 13.73 \text { domain yang } \\
\text { paling mengganggu terdapat pada } \\
\text { domain fisik. Sementara itu nilai } \\
\text { normal penilain kualitas hidup dengan } \\
\text { skor rata-rata } 20,00 \text {. }\end{array}$ \\
\hline 2. & 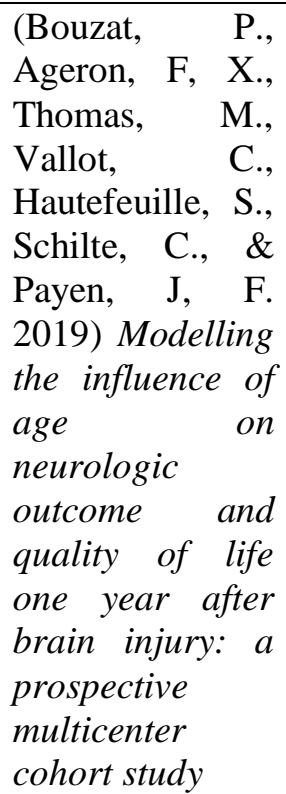 & $\begin{array}{l}\text { Tujuan dalam } \\
\text { penelitian ini } \\
\text { untuk } \\
\text { menggambarkan } \\
\text { hubungan dalam } \\
\text { kelompok } \\
\text { pasien TBI } \\
\text { dalam sistem } \\
\text { trauma regional. }\end{array}$ & $\begin{array}{l}\text { Desain Penelitian: } \\
\text { Cohort study } \\
\text { Sampel: } 427 \text { orang } \\
\text { Instrumen: Quesioner } \\
\text { Short-Form 12 (SF-12) }\end{array}$ & $\begin{array}{l}\text { Penelitian ini didapatkan hasil } \\
\text { penilaian kualitas hidup yaitu: } \\
\text { - Domain fisik dengan skor penilaian } \\
47( \pm 11) \\
\text { - Domain mental didapatkan skor rata- } \\
\text { rata } 42( \pm 12) \text { yang menyatakan } \\
\text { terdapat ketidakmampuan ringan. }\end{array}$ \\
\hline 3. & $\begin{array}{l}\text { (Verdugo, } \\
\text { Fernandez, } \\
\text { Gomez, Amor, } \\
\text { \& Aza, 2019) } \\
\text { Predictive } \\
\text { factors of quality } \\
\text { of life in } \\
\text { acquired brain } \\
\text { injury }\end{array}$ & $\begin{array}{lr}\text { Tujuan } & \text { dalam } \\
\text { penelitian ini } \\
\text { untuk menilai } \\
\text { kualitas hidup } \\
\text { dari rampel } \\
\text { pasien spanyol } \\
\text { dan } \\
\text { menganalisis } \\
\text { pengaruh } \\
\text { variabel } \\
\text { sosiodemografi }\end{array}$ & $\begin{array}{l}\text { Desain Penelitian: } \\
\text { Cross-sectional } \\
\text { Sampel: } 421 \text { responden } \\
\text { Instrumen: } \\
\text { CAVIDACE }\end{array}$ & $\begin{array}{l}\text { Penelitian ini didapatkan hasil yang } \\
\text { menyatakan, bahwa penilaian kualitas } \\
\text { hidup dengan nilai tertinggi terdapat } \\
\text { pada: } \\
\text { - Domain material well-being (MW)/ } \\
\text { domain kesejahteraan material. } \\
\text { - Domain Rights (RI)/ Hak, } \\
\text { sementara itu hasil penilaian dengan } \\
\text { nilai terendah didapatkan pada } \\
\text { - Domain personal development (PD)/ } \\
\text { pengembangan pribadi. }\end{array}$ \\
\hline
\end{tabular}




\begin{tabular}{|c|c|c|c|c|}
\hline No & $\begin{array}{l}\text { Nama Penulis, } \\
\text { Tahun dan } \\
\text { Judul Artikel }\end{array}$ & $\begin{array}{c}\text { Tujuan } \\
\text { Penelitian }\end{array}$ & Metode Penelitian & Hasil Penelitian \\
\hline & & $\begin{array}{l}\text { terkait cedera } \\
\text { tertentu terhadap } \\
\text { kualitas hidup }\end{array}$ & & $\begin{array}{l}\text { - Domain sosial inclusion (SI)/ inklusi } \\
\text { sosial. }\end{array}$ \\
\hline 4. & $\begin{array}{l}\text { (Haller, C, S., } \\
\text { Delhumeau, C., } \\
\text { Pretto, M, D., } \\
\text { Schumacher, R., } \\
\text { Pielmaier, L., } \\
\text { Rebetez, M, M, } \\
\text { L., Haller, G., \& } \\
\text { Walder, B. } \\
\text { 2017) Trajectory } \\
\text { of disability and } \\
\text { quality of life in } \\
\text { non-geriatric } \\
\text { and geriatric } \\
\text { survivors after } \\
\text { severe traumatic } \\
\text { brain injury }\end{array}$ & $\begin{array}{l}\text { Tujuan dalam } \\
\text { penelitian ini } \\
\text { untuk } \\
\text { menyelidiki } \\
\text { kecacatan dan } \\
\text { kualitas hidup } \\
(H R Q O L) \\
\text { terkait kesehatan } \\
3,6 \text { dan } 12 \\
\text { bulan setelah } \\
\text { cedera otak } \\
\text { traumatis }\end{array}$ & $\begin{array}{l}\text { Desain Penelitian: } \\
\text { Cohort-Study } \\
\text { Sampel: } 351 \text { responden } \\
\text { dengan durasi } 3 \text { bulan } \\
\text { pasca cedera kepala, } 340 \\
\text { responden dengan durasi } \\
\text { pasca cedera kepala } 6 \\
\text { bulan, dan } 305 \\
\text { responden dengan durasi } \\
12 \text { bulan pasca cedera } \\
\text { kepala } \\
\text { Instrumen: Quesioner } \\
\text { Short-Form } 12 \text { (SF-12) }\end{array}$ & $\begin{array}{l}\text { Penelitian ini didapatkan hasil yang } \\
\text { menyatakan peningkatan kualitas } \\
\text { hidup dilihat dari responden geriatrik } \\
\text { ataupun non-geriatrik, yang dinilai dari } \\
5 \text { domain penilaian yaitu } \\
\text { - Fisik } \\
\text { - Mental } \\
\text { - Emosional } \\
\text { - Interpersonal } \\
\text { - Kognitif. }\end{array}$ \\
\hline 5. & $\begin{array}{l}\text { (Weber, K, T., } \\
\text { Giumaraes,V, A. } \\
\text { Neto, O, M, P., } \\
\text { Leite, J, P., } \\
\text { Takayanagiu, } \\
\text { M., \& Pontelli, } \\
\text { T, E, G, S. 2016) } \\
\text { Predictors of } \\
\text { quality of life } \\
\text { after moderate } \\
\text { to severe } \\
\text { traumatic brain } \\
\text { injury }\end{array}$ & $\begin{array}{l}\text { Tujuan dalam } \\
\text { penelitian ini } \\
\text { untuk menilai } \\
\text { aspek kualitas } \\
\text { perawatan dan } \\
\text { kualitas hidup } \\
\text { pasca cedera } \\
\text { kepala. Tujuan } \\
\text { dalam penelitian } \\
\text { ini untuk } \\
\text { menilai kualitas } \\
\text { hidup dari } \\
\text { sampel pasien } \\
\text { spanyol dan } \\
\text { menganalisis } \\
\text { pengaruh } \\
\text { variabel } \\
\text { sosiodemografi } \\
\text { terkait cedera } \\
\text { tertentu terhadap } \\
\text { kualitas hidup. }\end{array}$ & $\begin{array}{l}\text { Desain Penelitian: } \\
\text { Studi longitudinal dan } \\
\text { deskriptif } \\
\text { Sampel: } 50 \text { orang } \\
\text { Instrumen: Quesioner } \\
\text { WHOQOL-BREF }\end{array}$ & $\begin{array}{l}\text { Penelitian ini didapatkan hasil usia } \\
\text { dan Length of stay (LOS) merupakan } \\
\text { prediktor independent QOL setelah } \\
\text { TBI sedang hingga berat, yang } \\
\text { menjadi pengaruh dalam penurunan } \\
\text { kualitas hidup. }\end{array}$ \\
\hline 6. & $\begin{array}{l}\text { (Theadom, A., } \\
\text { Parag, } \\
\text { Dowell,T., } \\
\text { Mcpherson, K., } \\
\text { Collo, S, B., } \\
\begin{array}{l}\text { Jones, K., } \\
\text { Ameratunga, }\end{array}\end{array}$ & $\begin{array}{lr}\text { Tujuan } & \text { dari } \\
\text { penelitian ini } \\
\text { adalah untuk } \\
\text { menentukan } \\
\text { sifat dan } \\
\text { frekuesi } \\
\text { kesulitan yang }\end{array}$ & $\begin{array}{l}\text { Desain Penelitian: } \\
\text { Studi kohort- } \\
\text { longitudinal } \\
\text { Sampel: } \\
\text { 341 pasien }\end{array}$ & $\begin{array}{l}\text { Penelitian ini didapatkan hasil yang } \\
\text { menyatakan terdapat penurunan } \\
\text { kualitas hidup pada pasien pasca } \\
\text { cedera kepala yang dilihat dari: } \\
\text { - Aspek mental yang menyatakan skor } \\
\text { awal } 107(70,9) \text { menjadi } 139(47,9) \\
\text { setelah } 12 \text { bulan pasca cedera }\end{array}$ \\
\hline
\end{tabular}




\begin{tabular}{|c|c|c|c|c|}
\hline No & $\begin{array}{l}\text { Nama Penulis, } \\
\text { Tahun dan } \\
\text { Judul Artikel }\end{array}$ & $\begin{array}{c}\text { Tujuan } \\
\text { Penelitian }\end{array}$ & Metode Penelitian & Hasil Penelitian \\
\hline & $\begin{array}{lr}\text { S.,\& } & \text { Feigin, } \mathrm{V}, \\
\mathrm{L} ., & 2015) \\
\text { Persistent } & \\
\text { problem } & 1 \\
\text { after } & \text { years } \\
\text { traumatic } & \text { mild } \\
\text { injury } & \end{array}$ & $\begin{array}{l}\text { di alami dan } \\
\text { untuk } \\
\text { mengidentifikasi } \\
\text { prediktor hasil } \\
\text { yang merugikan } \\
\text { selamar satu } \\
\text { tahun setelah } \\
\text { cedera kepala }\end{array}$ & $\begin{array}{l}\text { Instrumen: Quesioner } \\
\text { Short Form 36, (SF-36) }\end{array}$ & $\begin{array}{l}\text { - Aspek komponen fisik skor awal } 112 \\
(75,7) \text { menjadi } 140(48,1) \\
\text { Aspek kognitif yang menjadi aspek } \\
\text { paling banyak penurunan dengan skor } \\
\text { rata-rata } 112(75,7) \text { menjadi } 138(47,4) \\
\text { setelah } 12 \text { bulan pasca cedera kepala. } \\
\text { Nilai skor rata-rata menyatakan nilai } \\
\text { yang lebih tinggi menunjukkan hasil } \\
\text { yang lebih buruk, dan nilai yang lebih } \\
\text { tinggi menunjukkan hasil penilaian } \\
\text { yang lebih baik bergantung dengan } \\
\text { domain penilaina kualitas hidup pada } \\
\text { kuesioner Short-form } 36 \text {. }\end{array}$ \\
\hline 7. & $\begin{array}{l}\text { (Sharma, Jain, } \\
\text { Sharma, A, } \\
\text { Mittal, \& Gupta, } \\
\text { 2015) Study of } \\
\text { quality of life in } \\
\text { traumatic brain } \\
\text { injury }\end{array}$ & $\begin{array}{l}\text { Tujuan dalam } \\
\text { penelitian ini } \\
\text { untuk menilai } \\
\text { Qualitas hidup } \\
(Q O L) \text { pada } \\
\text { individu dengan } \\
\text { TBI dan } \\
\text { hubungan } \\
\text { dengan faktor } \\
\text { demografi, } \\
\text { insomnia } \\
\text { posttraumatic, } \\
\text { dan yang } \\
\text { berhubungan } \\
\text { dengan cedera. }\end{array}$ & $\begin{array}{l}\text { Desain Penelitian: } \\
\text { Cross-Sectional } \\
\text { Sampel: } 204 \text { pasien } \\
\text { Instrumen: } \\
\text { Quesioner WHOQOL- } \\
B R E F\end{array}$ & $\begin{array}{l}\text { Penelitian ini didapatkan hasil yang } \\
\text { menyatakan bahwa terdapat penurunan } \\
\text { pada keempat domain penilaian } \\
\text { kualitas hidup, yaitu pada: } \\
\text { - Domain kesehatan fisik dengan skor } \\
\text { rata-rata } 58,26 \\
\text { - Domain psikologis dengan skor rata- } \\
\text { rata } 61,0 \text {. } \\
\text { - Domain hubungan sosial dengan skor } \\
\text { rata-rata } 60,16 \text {. } \\
\text { - Domain kesehatan lingkungan yang } \\
\text { menjadi domain paling tidak } \\
\text { memuaskan dengan skor rata-rata } \\
56,70 \text {. }\end{array}$ \\
\hline
\end{tabular}

\section{PEMBAHASAN}

Bersumber pada hasil literature yang di review dari 7 artikel penelitian didapatkan hasil bahwa umur pasien mengalami cedera kepala lebih banyak pada umur $<65$ tahun ialah sebanyak (84, 43\%). Didukung penelitian Coronado,et.al. (2011) yang melaporkan ratarata penderita luka kepala merupakan mereka yang masih dalam umur produktif. ialah 18- 40 tahun, dimana pada umur tersebut seorang mempunyai keahlian yang maksimal buat beraktivitas. Bersumber pada 7 artikel penelitian yang review melaporkan pria $(70,78 \%)$ sangat dominan hadapi cedera kepala. Bersumber pada hasil statment penelitian Rawis, et.al (2016) melaporkan sebagian aspek yang bisa jadi pengaruhi tingginya angka peristiwa cedera kepala pada pria ialah aktivitas fisik dan pekerjaan pada laki-laki lebih beresiko dibandingkan dengan perempuan misalnya 
pekerjaan bangunan dan pengendara sepeda motor.

Berdasarkan hasil dari literature review menggunakan 7 artikel penelitian kuantitatif yang berkaitan dengan gambaran kualitas hidup pasca cedera kepala didapatkan hasil yang sesuai dengan artikel yang telah direview. Desain penelitian yang digunakan Sharma, et al. (2015) \& Verdugo, et al. (2019) yaitu desain cross-sectional, penelitian yang dilakukan oleh Theadom, et al. (2015) \& Weber, et al. (2016) mengunakan desain penelitian studi longitudinal, sementara itu penelitian yang dilakukan oleh Haller, et al. (2017) \& Bouzat, et al. (2019) menggunakan desain penelitian cohort-study, satu dari artikel penelitian tidak menjelaskan desain penelitian yang digunakan yaitu pada penelitian Dainter, et al. (2019).

Pada artikel penelitian ini terdapat perbedaan penggunaan instrumen penelitian (kuesioner), diantaranya pada penelitian yang dilakukan oleh Dainter, et al. (2019) menggunakan kuesioner WHOQOL-100 kuesioner ini terdiri dari 100 item yang terurai menjadi 24 aspek yang selanjutnya terbagi atas 6 besar domain penilaian kualitas hidup yaitu domain fisik, domain psikologis, domain hubungan sosial, domain lingkungan, domain kemandirian, dan domain spritualitas. Selain itu terdapat 2 artikel penelitian yang menggunakan kuesioner WHOQOL-BREF yaitu pada penelitian Sharma, et al. (2015) dan Weber, et al. (2016), kuesioner WHOQOL-BREF yang dikembangkan oleh World Health Organization (WHO) merupakan instrumen yang digunakan untuk mengukur kualitas hidup yang terdiri dari 4 domain yaitu: domain fisik, domain psikologis, domain sosial, domain lingkungan, yang terdiri dari 24 pertanyaan.

Instrumen WHOQOL-BREF lebih sering digunakan untuk melakukan penilaian kualitas hidup terhadap responden dengan usia lanjut. Selain itu pada penelitian yang dilakukan oleh Theadom,et al. (2015) menggunakan kuesioner short-form 36 (SF-36) merupakan instrumen kualitas hidup yang umum (generic scale) yang bersifat baku untuk menilai kualitas hidup dengan penyakit kronis, instrument ini terdiri dari 8 aspek penilaian yaitu: aspek fungsi fisik, aspek peran fisik, aspek rasa nyeri, aspek kesehatan umum, aspek fungsi sosial, aspek vitalitas, aspek peran emosi dan aspek kesehatan mental yang secara keseluruhan terdiri dari 34 pertanyaan, kuesioner ini sering digunakan karna dinilai lebih lengkap dibandingkan dengan kuesioner penilaian lainnya (Ningrum, 2016).

Pada artikel penelitian yang dilakukan oleh Haller, et al. (2017) \& Bouzat, et al. (2019) menggunakan kuesioner short-form 12 (SF-12) merupakan hasil pengembangan dari SF-36 didalam kuesioner SF-12 terdiri dari 12 pertanyaan yang mencangkup aspek dari kuesioner SF-36 kelebihan dari kuesioner ini 
dinilai lebih singkat dibandingkan dengan kuesioner SF-36 (Fallah, et al. 2017). Sedangkan pada penelitian Verdugo, et al. (2019) menggunakan skala CAVIDACE yang merupakan instrumen spesifik penyakit yang bertujuan untuk menilai hasil $Q O L$ dari orang dewasa dengan Acquired Brain Injury (ABI), skala CAVIDACE terdiri dari 64 item dan 8 domain yaitu: Emotional Well- being (EW), Interpersonal Relationship (IR), Material Wellbeing (MW), Personal Development (PD), Physical Well-being (PW), Self-Determination (SD), Social Inclution (SI), Rights (RI).

Tabel 9. Gambaran kualitas hidup pasien pasca cedera kepala artikel yang direview

\begin{tabular}{llll}
\hline \multirow{2}{*}{ No } & Gambaran kualitas hidup & Jumlah artikel & Presentase \\
\cline { 3 - 4 } & & $\mathrm{N}$ & $\%$ \\
\hline 1 & Baik & 1 & $14,29 \%$ \\
\hline 2 & Buruk & 6 & $85,71 \%$ \\
\hline Jumlah & & 7 & $100 \%$ \\
\hline
\end{tabular}

Berdasarkan 7 artikel yang dilakukan review didapatkan 6 dari 7 artikel yang menyatakan terdapat penurunan kualitas hidup pada pasien pasca mengalami cedera kepala, dan 1 artikel yang menyatakan terdapat peningkatan kualitas hidup.

Tabel 10. Domain Kualitas hidup yang paling terganggu

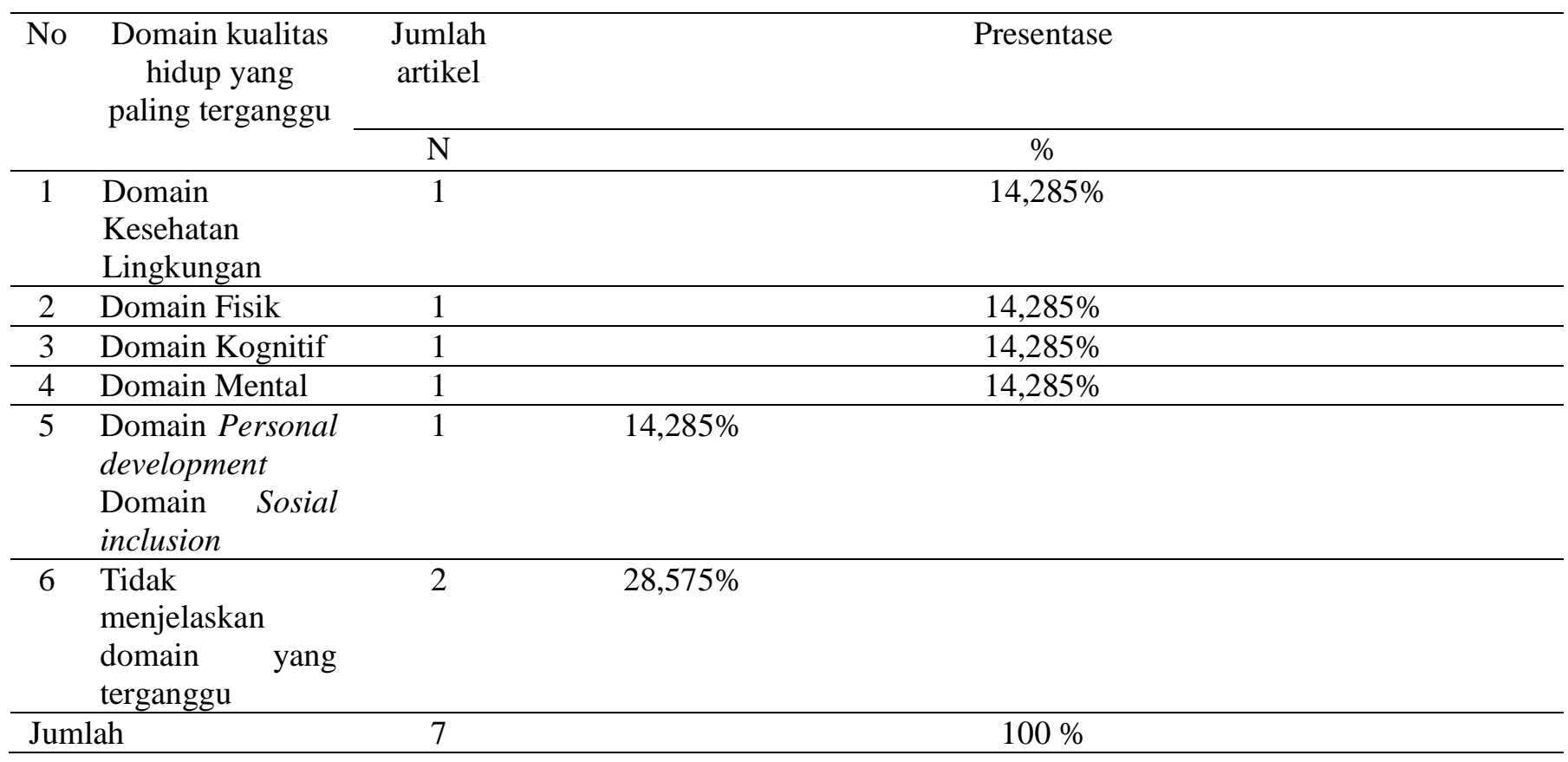


Berdasarkan ke 7 artikel yang dilakukan review didapatkan hasil yang berbeda disetiap domain penilaian kualitas hidup yang paling mengganggu diantara domaian penilaian lainnya.

Berdasarkan 7 artikel penelitian yang direview didapatkan hasil yang berbeda-beda dari setiap penelitian, pada penelitian yang dilakukan oleh Sharma, et al. (2015) menyatakan dari keempat domain yaitu domain fisik, psikologi, sosial dan kesehatan lingkungan, domain kesehatan lingkungan menjadi domain yang paling tidak memuaskan, hal ini disebabkan karna banyak faktor yang mungkin bertanggung jawab terhadap kualitas hidup yang lebih rendah, termasuk fungsi fisik yang buruk, kelelahan, gangguan tidur, rasa sakit dan depresi, yang dikaitkan dengan melemahnya dukungan sosial dan kontak dengan lingkungan sekitar.

Hasil penelitian Sharma, et al. (2015) terdapat perbedaan dengan penelitian Dainter, et al. (2019) yang menyatakan domain fisik menjadi domain paling tidak memuaskan. Penyataan ini didukung teori yang menyatakan bahwa cedera kepala memunculkan kelainan struktural maupun fungsional pada jaringan otak, bahkan dapat mengganggu kesadaran serta menimbulkan kerusakan kemampuan kognitif dan fisik sehingga dapat mempengaruhi kemampuan dalam melakukan kegiatan (Marx, Hockbergem \& Walls, 2014).
Selain itu menurut World Health Organization (WHO) permasalahan cedera kepala menjadi permasalahan sangat berbahaya menimbulkan kematian serta kecacatan permanen pada penderita, sekitar $40 \%$ - 50\% mengalami kecacatan permanen ataupun disabilitas. Pada penelitian Theadom, et al. (2015) memaparkan hasil penelitian yang berbeda, yang mana pada penelitian ini menyatakan dari ketiga domain penilaian kualitas hidup yaitu kognitif, mental, dan fisik, domain mental menjadi domain penilaian yang paling memuaskan sedangkan domain kognitif menjadi domain yang paling tidak memuaskan, pernyataan ini sama degan penelitian yang dilakukan oleh Van eijck, et al. (2018) yang menyatakan domain penilaian kualitas hidup yang paling tidak memuaskan terdapat pada domain kognisi dengan skor rata-rata 64,3 sedangkan domain yang paling memuaskan terdapat pada kesejahteraaan emosional dengan skor rata-rata 80,0 .

Hasil penelitian yang dilakukan Bouzat, et al. (2019) tidak sejalan dengan hasil penelitian Theadom, et al. (2015), yang mana pada penelitian Bouzat, et al. (2019) menyatakan bahwa dari 5 domain penilaian kualitas hidup dengan menggunakan instrumen SF-12 pada penelitian ini hanya memfokuskan penilaian pada domain mental dan fisik, yang mana dari kedua domain tersebut domain mental yang paling tidak memuaskan. 
Hasil penelitian yang berbeda juga disampaikan dalam penelitian yang dilakukan oleh Verdugo, et al. (2019) yang menyatakan dari 8 domain penilaian kualitas hidup. Domain yang paling mengalami ketidak puasan terdapat pada domain personal development (PD), dan sosial inclusion (SI), didalam penelitian dinyatakan bahwa domain yang terganggu merupakan keterbatasan yang khas terjadi pada pasien dengan Acquired Brain Injury (ABI), yaitu hubungan sosial dan masyarakat, partisipasi otonomi pribadi, kegiatan hidup sehari-hari dan kesulitan menyelesaikan masalah.

Pada penelitian yang dilakukan Weber, et al. (2016) menyatakan hasil penelitian yang dilihat dari prediktor penurunan kualitas hidup yaitu umur dan length of stay (LOS), semakin tinggi usia semakin baik kualitas hidup yang dirasakan oleh pasien menurut pernyataan peneliti orang dewasa yang lebih tua dengan traumatic brain injury (TBI) dapat mempertimbangkan perubahan dalam kesehatan atau gejala sebagai konsekuensi dari proses penuaan dari pada efek yang disebabkan oleh TBI, dalam penelitian ini juga dijelaskan orang dewasa yang lebih muda memiliki kesehatan yang lebih memuaskan. Dilihat dari prediktor LOS semakin tinggi LOS semakin buruk kualitas hidup, dapat dijelaskan oleh fakta bahwa LOS mencerminkan tingkat keparahan terkait faktor dan dengan demikian secara langsung mempengaruhi kualitas hidup.

Penelitian yang dilakukan oleh Haller, et al. (2017) yang menyatakan hasil penelitian yang berbeda dari penelitian lainnya, yaitu kecacatan dan kualitas hidup membaik setelah TBI antara 3-12 bulan, penilaian dari aspek fisik menunjukkan adanya peningkatan yang signifikan yang terjadi pada pasien non-geriatri, sedangkan pada pasien geriatri kemungkinan mencapai signifikan lebih rendah.

Pada aspek mental dilaporkan tidak terdapat penurunan fungsi baik pada responden geriatri dan non- geriatri, hal tersebut sama dengan aspek fungsikognitif yang menyatakan tidak terdapat perubahan atau penurunan pada responden 3, 6 dan 12 bulan pasca cedera kepala. Pernyataan hasil pada penelitian ini sejalan dengan pernyataan dalam penelitian Sharma,et al. (2015) yaitu pasien dengan durasi pasca cedera yang lebih lama ( $>6$ bulan) memiliki kualitas hidup yang lebih baik dibandingkan dengan pasien dengan durasi cedera kepala yang lebih rendah $(<3$ bulan).

\section{SIMPULAN}

Setelah serangkaian proses dilalui berdasarkan hasil literature review dengan topik gambaran kualitas hidup pasien pasca cedera kepala, peneliti mengambil kesimpulan dari 7 artikel yang direview yang membahas atau menggambarkan kualitas hidup pasien 
pasca cedera kepala. 6 artikel penelitian mengatakan terdapat penurunan kualitas hidup pasien pasca mengalami cedera kepala. Terdapat 1 artikel yang menyatakan tidak terganggunya kualitas hidup pasien pasca mengalami cedera kepala.

\section{SARAN}

Hasil literature review ini dapat memberikan informasi terkait perubahan dan aspek yang terganggu pada pasien setelah mengalami cedera kepala. mengalami cedera kepala. Evaluasi outcome fungsional perlu dilakukan pada pasien baik pada 3 bulan, 6 bulan atau 12 bulan setelah keluar dari rumah sakit, tindakan ini penting dilakukan untuk program rehabilitasi, dan untuk mengukur keefektifan perkembangan pasien dari rangkaian pengobatan yang sudah dilakukan. Menurut peneliti efek atau domain yang terganggu pada setiap pasien pasca mengalami cedera kepala dapat berbeda-beda tergantung pada tingkat cedera yang dialami pasien, dan penggunaan domain penilaian yang berbeda disetiap artikel.

\section{DAFTAR RUJUKAN}

Bouzat, P., Ageron, F, X., Thomas, M., Vallot, C., Hautefeuille, S., Schilte, C., \& Payen, J, F. (2019). Modelling the influence of age on neurologic outcome and quality of life one year after traumatic brain injury: A prospective multicenter cohort study. Journal of Neurotrauma. Diakes pada 15 Mei 2020.
Coronado, V,. Xu, L., Basavaraju, S., McGuire, L., Wald, M., Faul, M., \& Hemphill, J. (2011). Surveillance for traumatic brain injury related deaths United States, 1997-2007. Center For Disease Control and Prevention, 60, 132. Diakses pada 9 Agustus 2020.

Dainter, K, M., Mckinlay, A., \& Grace, R, C,. (2019). Change in life roles and quality of life for older adults after traumatic brain injury. Ios Press and the Authors. 299-307. Diakses pada 22 Mei 2020.

Dewi, S. R. (2014). Buku ajar keperawatan gerontik. Yogyakarta: Budi utama.

Fallah, N, M., Putranto, R., Setyohadi, B, \& Rinaldi, I. (2019). Uji keandalan dan kesahihan kuesioner kualitas hidup short-form 12 quality of life quesionnaire in rheumatoid arthtritis patien. Jurnal Penyakit Dalam Indonesia. 4(3). Diakses pada 12 juli 2020.

Gooday, H, M, K., Pentland, B., Fiona, S., \& Whyte, M. (2019). Outcome and prognosis after head injury. Karolinska Institute university library (Cambridge Core).

Haller, C, S., Delhumeau, C., Pretto, M, C., Schumacher, R.,Pielmaier,L., Rebetez, M, M, L., Haller, G., \& Walder, B,. (2017). Trajectory of disability and quality of life in non- geriactric and geriactric survivors after savere traumatic brain injury. Brain Injury. Diakses pada 20 Mei 2020.

Haryono, R., \& Utami, M, P, S. (2019). Keperawatan medikal bedah II. Yogyakarta: Pustaka Baru Press. 
Marx, J., Hockbergerm, R., \& Walls, R. (2014). Rosen's Emergency medicine concepts and clinical practie. Philadelphia: Elsevier Sauders.

Ningrum, W, A, C., Hidayati, S,. \& Rahma. (2016). Kualitas hidup pasien urolithiasis pada komponen fisik dan komponen mental dengan instrumen short-form 36 (SF-36). Jurnal Care. 4(3). Diakses pada 12 juli 2020.

Rawis, M, L., Lalenoh, D, C., \& Kumaat, L, T. (2016). Profil pasien cedera kepala sedang dan berat yang dirawat di ICU dan HCU. Jurnal e-Clinic, Vol 4(2). Diakses pada 9 Agustus 2020.

Riskesdas 2018. (2018). Hasil Utama Riskesdas Kesehatan. 116- 121. Retrievedhttp://www.kesmas.kemkes.g o.id/assets/upload/dir_519d41d8cd98f 00/files/Hasil-riskesdas-2018_1274. pdf Diakses tanggal 3 JanuSatyanegara. (2014). Ilmu bedah saraf edisi $V$. Jakarta: Gramedia Pustaka Utama.

Sharma, A., Jain, A., Sharma, A., Mittal, R, S., \& Gupta, I, D,. (2015). Study of quality of life in traumatic brain injury, Indian $J$ Neurotrauma. $12 . \quad 2-9$. Diakses pada 20 Mei 2020.

Siponkoski, S. T., Wilson, L., Steinbuchel, N, L., Sarajuuri, J., \& Koskinen,S,. (2013). Quality of life after traumatic brain injury: Finnish experience of the qolibri in residental rehabilitation. Journal Compilation Foundation of Rehabilitation Information 45: 835842. Diakses pada 10 Januari 2020.
Stewart, R. M., Rotondo, M, F., Henry, S, M., Drago, M., Merrick, C., Haskin, D, S., Paterson, N., Menendez, A., Kidd, S., Flor, R.,\& Garcia,J. (2018). Advanced Trauma Life Support (ATLS). Chicago: American College of Surgions. Diakses tanggal 3 Januari 2020.

Tarwoto. (2013). Keperawatan medikal bedah edisi II. Jakarta: CV. Sagung Seto.

Theadom, A., Parag, V., Dowell, T., Mcpherson., Starkey, N., Collo, S, B., Jones, K., Ameratunga, S., \& Feigin, V, L. (2016). Persisten problems 1 years after mild traumatic brain injury: A longitudinal population study in New Zealand. British Journal of General Practice. Diakses pada 15 Mei 2020.

Van eijck, M., Naalt, J, V, D., Jongh, M, D., Schoonman,G., Oldenbeuving, A., Peluso, J., Vries, J, D., \& Roks, G. (2018). Patients with diffuse axonal injury can recover to a favourable long-term functional and quality of life outcome. Journal of Neurotrauma. Diakses pada 14 Juli 2020.

Verdugo, M, A., Fernandez. M., Gomez, L, E., Amor, A, M., \& Aza, A. (2019). Predictive factors of quality of life in aquired brain injury. International Journal of Clinical and. Psychology. 19. 189-197. Diakses pada 15 Mei 2020.

Weber, K, T., Guimaraes, V, A., Neto, O, M, P., Leite, J, P., Takayanagui, O, M., \& Pontelli, T, E, G, S. (2016). Predictors of quality of life after moderate to savere traumatic brain injury. Arq Neuropsiquiatr. $\quad 74(5) . \quad$ 409-415. Diakese pada 22 Mei 2020. 
Zwingly, P., Oley, M. C.,\& Limpeleh, H. P. (2015). Gambaran kualitas hidup pasien cedera kepala pasca mengalami operasi periode Januari 2012Desember 2013 di RSUP PROF.DR.R.D. Kandou Manado. Jurnal e-clinic (eCI), 3(1). Diakses tanggal 03 Januari 2 MKZ 